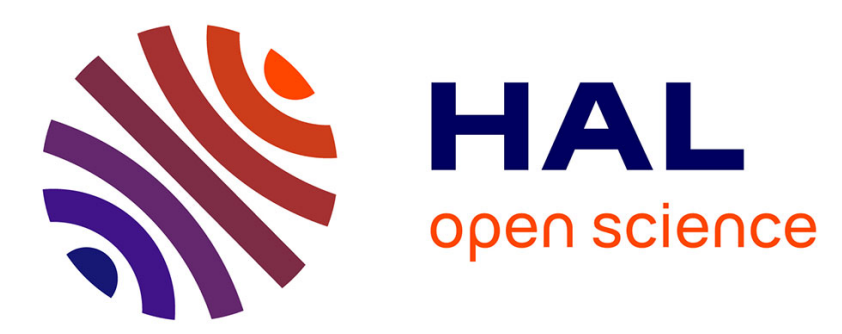

\title{
Soil enzyme dynamics in chlorpyrifos-treated soils under the influence of earthworms
}

Juan C Sanchez-Hernandez, J. Notario del Pino, Yvan Capowiez, Christophe Mazzia, Magali Rault

\section{- To cite this version:}

Juan C Sanchez-Hernandez, J. Notario del Pino, Yvan Capowiez, Christophe Mazzia, Magali Rault. Soil enzyme dynamics in chlorpyrifos-treated soils under the influence of earthworms. Science of the Total Environment, 2018, 612, pp.1407-1416. 10.1016/j.scitotenv.2017.09.043 . hal-02089673

\section{HAL Id: hal-02089673}

\section{https://hal-univ-avignon.archives-ouvertes.fr/hal-02089673}

Submitted on 10 Apr 2019

HAL is a multi-disciplinary open access archive for the deposit and dissemination of scientific research documents, whether they are published or not. The documents may come from teaching and research institutions in France or abroad, or from public or private research centers.
L'archive ouverte pluridisciplinaire HAL, est destinée au dépôt et à la diffusion de documents scientifiques de niveau recherche, publiés ou non, émanant des établissements d'enseignement et de recherche français ou étrangers, des laboratoires publics ou privés. 


\title{
Soil enzyme dynamics in chlorpyrifos-treated soils under the influence of earthworms
}

\author{
Juan C. Sanchez-Hernandez ${ }^{\text {a,* }}$, J. Notario del Pino ${ }^{\text {b }}$, Yvan Capowiez ${ }^{\text {c }}$, Christophe Mazzia ${ }^{\text {d, Magali Rault }}{ }^{\text {d }}$ \\ ${ }^{a}$ Ecotoxicology Lab, Fac. Environmental Science and Biochemistry, University of Castilla-La Mancha, Toledo, Spain \\ b Department of Animal Biology, Soil Science and Geology, University of La Laguna, Canary Islands, Spain \\ c INRA, UMR 1114, EMMAH, Site Agroparc, Avignon, France \\ ' Univ Avignon, Aix Marseille Univ, CNRS, IRD, IMBE, Pôle Agrosciences, 301 rue Baruch de Spinoza, BP 21239, 84916 Avignon, France
}

\section{H I G H L I G H T S}

- Earthworm activity did not accelerate degradation rate of chlorpyrifos.

- Earthworms increased soil enzyme activities in chlorpyrifos-contaminated soils.

- Chlorpyrifos strongly inhibited cholinesterase and carboxylesterase activities of earthworms.

- Soil carboxylesterase had a functional role as a chlorpyrifos-oxon scavenger.

\section{Keywords:}

Biomarkers

Soil enzymes

Organophosphorus insecticides

Enzyme-based indexes

Integrated biomarker index

Oxidative stress

Esterases

\section{GR A P H I C A L A B S T R A C T}

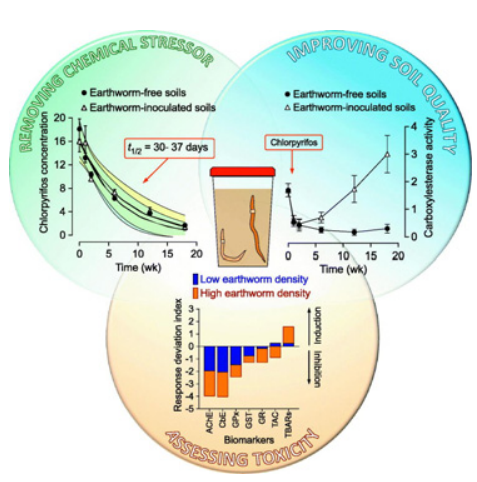

\section{A B S T R A C T}

Earthworms contribute, directly and indirectly, to contaminant biodegradation. However, most of bioremediation studies using these annelids focus on pollutant dissipation, thus disregarding the health status of the organism implied in bioremediation as well as the recovery of indicators of soil quality. A microcosm study was performed using Lumbricus terrestris to determine whether earthworm density ( 2 or 4 individuals $/ \mathrm{kg}$ wet soil) and the time of exposure $(1,2,6,12$, and $18 \mathrm{wk}$ ) could affect chlorpyrifos persistence in soil initially treated with $20 \mathrm{mg}$ active ingredient $\mathrm{kg}^{-1}$ wet soil. Additionally, selected earthworm biomarkers and soil enzyme activities were measured as indicators of earthworm health and soil quality, respectively. After an 18-wk incubation period, no earthworm was killed by the pesticide, but clear signs of severe intoxication were detected, i.e., 90\% inhibition in muscle acetylcholinesterase and carboxylesterase $(\mathrm{CbE})$ activities. Unexpectedly, the earthworm density had no significant impact on chlorpyrifos dissipation rate, for which the measured half-life ranged between $30.3 \mathrm{~d}$ (control soils) and $44.5 \mathrm{~d}$ (low earthworm density) or $36.7 \mathrm{~d}$ (high earthworm density). The dynamic response of several soil enzymes to chlorpyrifos exposure was examined calculating the geometric mean and the treated-soil quality index, which are common enzyme-based indexes of microbial functional diversity. Both indexes showed a significant and linear increase of the global enzyme response after 6 wk of chlorpyrifos treatment in the presence of earthworms. Examination of individual enzymes revealed that soil $\mathrm{CbE}$ activity could decrease chlorpyrifos-oxon impact upon the rest of enzyme activities. Although $L$. terrestris was found not to accelerate chlorpyrifos dissipation, a significant increase in the activity of soil enzyme activities was achieved

\footnotetext{
* Corresponding author.

E-mail address: juancarlos.sanchez@uclm.es (J.C. Sanchez-Hernandez).
} 
compared with earthworm-free, chlorpyrifos-treated soils. Therefore, the inoculation of organophosphorus-contaminated soils with $L$. terrestris arises as a complementary bioremediation strategy in terms of recovery of soil biochemical performance and quality.

\section{Introduction}

Pesticide use in conventional agriculture is a hazard to soil quality and may contribute to long-term land degradation (Tilman et al., 2002; Stavi et al., 2016). There is a broad consensus that soil is a major sink for pesticides, and multiple physicochemical and biological processes contribute jointly to their transformation and degradation. Furthermore, toxic metabolites may be produced during these degradation processes. Therefore, the persistence of pesticides in soils may pose a serious threat to non-target organisms (Devine and Furlong, 2007), groundwater quality (Arias-Estévez et al., 2008) or soil microbial processes (Gianfreda and Rao, 2008). The awareness about such risks has been a good reason to develop methodologies aimed to accelerate the degradation of pesticide residues, especially along the last two decades (Megharaj et al., 2011). However, low-cost and sustainable approaches to preserve soil quality at the long term are nowadays conceived as a major challenge. Accordingly, the use of organic amendments such as compost has shown to be an efficient strategy to reduce contaminant persistence and toxicity, primarily because of their direct beneficial effects on soil microbial diversity and proliferation (Fenoll et al., 2014; Rodríguez-Liébana et al., 2014). However, and occasionally, these strategies are not as efficient as foreseen, because of reasons such as the occurrence of contaminants bound to dissolved organic matter (Li et al., 2005), inaccessibility of contaminants to microbial degradation (Megharaj et al., 2011), or decreased microbial activity and biomass caused by nutrient depletion or adverse environmental conditions at the time of application (Singh and Walker, 2006).

In this context, earthworms, either naturally present in the contaminated soil or intentionally introduced, are a promising complementary strategy capable to solve, at least in part, some of these drawbacks (Butt, 2008). Because of their intimate contact with soil, earthworms induce significant changes in soil structure and chemical-biological properties (Edwards, 2004). These organisms may be used as a driving force in contaminant dissipation via their impact on microbial dispersal, contaminant bioavailability and organic matter decomposition. To date, the research on earthworm-assisted bioremediation has tended to focus primarily on soil physicochemical changes affecting the partitive properties of the contaminant, changes on soil microbial communities implied in contaminant degradation, and toxic effects on earthworms in terms of survival and reproduction rate (Hickman and Reid, 2008; Rodriguez-Campos et al., 2014; Martinkosky et al., 2017). However, far too little attention has been paid to sublethal effects on earthworms, and soil enzyme dynamics during bioremediation; the latter being recommended bioindicators of soil quality and fertility (Paz-Ferreiro and $\mathrm{Fu}, 2013)$.

It is generally accepted that soil enzymes come mainly from microbes (Burns et al., 2013), so it is reasonable to expect that microbial proliferation during bioremediation should trigger an increase of soil enzyme activities. Indeed, some studies have demonstrated that proliferation of soil microbes associated with soil-dwelling earthworm species (Lumbricus terrestris and Metaphire guillelmi), increases enzyme activities related to C, N and P cycling (Tao et al., 2009; Kizilkaya et al., 2010; Dempsey et al., 2013). Despite this direct relationship, no studies have examined such functional association during bioremediation of pesticide-contaminated soils. On the other hand, some pesticide classes (e.g., organophosphorus) may inhibit the activity of soil enzymes such as phosphatases and $\beta$-glucosidase (Riah et al., 2014). Moreover, biodegradation of pesticides may generate metabolites more toxic than their parent compounds. This is true of chlorpyrifos, an organophosphorus pesticide whose main metabolites (chlorpyrifosoxon and 3,5,6-trichloro-2-pyridinol) are highly toxic to soil enzyme activities (Sanchez-Hernandez et al., 2017) and soil microbes (John and Shaike, 2015). These studies question, therefore, whether microbial proliferation during bioremediation necessarily results in an enhancement of the activity of soil enzymes.

This study sets out to examine the impact of $L$. terrestris on the activity of soil enzymes during the degradation of chlorpyrifos. Therefore, the aims were: 1 ) to determine whether $L$. terrestris activity reduced the half-life of chlorpyrifos by comparing earthworm-free and earthworm-inoculated soils at two individual densities, 2) to assess sublethal long-term effects of chlorpyrifos upon earthworms through the measurement of biomarkers linked to the mode of toxic action of chlorpyrifos, and 3) to examine the dynamics of soil enzyme activities, relevant in terms of biogeochemical cycling and pesticide detoxification. Our findings will help to understand the importance of earthworms in the maintenance of soil biochemical performance under environmental stress (i.e., chemical pollution).

\section{Materials and methods}

\subsection{Microcosm setup}

The impact of $L$. terrestris activity on chlorpyrifos degradation kinetics was examined using a repeated measures experimental design with two inter-subject factors (earthworm density and soil amendment, two levels for each one) and one intra-subject factor (time $=0,1,2,6,12$, and $18 \mathrm{wk}$ ). The soil sample (Antrosol, IUSS Working Group WRB, 2015) used for this experiment was loamy in texture, with a maximum water holding capacity of $0.31 \pm 0.01 \mathrm{~g} \mathrm{H}_{2} \mathrm{O} \mathrm{g}^{-1}$ dry soil, and was collected from a rural area in Toledo Province (Spain). Adult earthworms were purchased from a commercial supplier (Decathlon ${ }^{\circledR}$, Toledo, Spain), kept in plastic containers $(345 \times 325 \times 150 \mathrm{~mm})$ for acclimatization at $15^{\circ} \mathrm{C}$ and permanent darkness, and periodically fed with litter (Morus alba) free of small branches and lignified tissues.

The experimental design involved the following treatments $(n=6$ replicates): 1) control treatment (earthworm- and litter-free soils), 2) litter treatment (earthworm-free soils amended with $8 \mathrm{~g}$ of litter per replicate), 3) low-density treatment (soil containing four earthworms per replicate; body mass $=3.90 \pm 1.01 \mathrm{~g}$, mean $\pm \mathrm{SD}, n=24$ individuals), and 4) high-density treatment (soil containing eight earthworms per replicate; body mass $=3.59 \pm 0.97 \mathrm{~g}$, mean $\pm \mathrm{SD}, n=48$ individuals). Each replicate held $2 \mathrm{~kg}$ of wet soil, so earthworm densities in our study represented the limits of the optimal density (3-5 adult individuals $1^{-1}$ soil) recommended for culturing $L$. terrestris (Lowe and Butt, 2005). Chlorpyrifos [0,0-diethyl 0-3,5,6-trichloropyridin-2-yl phosphorothioate] was used as an emulsifiable formulation (Cuspide ${ }^{\circledR}$ 48E, 48\% chlorpyrifos, Comercial Química Massí, S.A., Barcelona, Spain). Following the instructions from the manufacturer, the pesticide was dissolved in water and sprayed onto the soil up to a nominal concentration of $20 \mathrm{mg}$ active ingredient $\mathrm{kg}^{-1}$ wet soil, being this dose chosen according to the range of concentrations detected in agricultural soils (Racke, 1993). Spiking of soil with chlorpyrifos was performed as follows: wet soil $(2 \mathrm{~kg})$ was placed in a plastic tray $(440 \times 290$ $\times 70 \mathrm{~mm}$ ) and sprayed with $50 \mathrm{ml}$ of $0.8 \mathrm{mg} \mathrm{ml}^{-1}$ chlorpyrifos solution; afterwards, the soil was carefully mixed for homogenization and placed in a plastic container $(145 \times 140 \times 120 \mathrm{~mm})$ with a holed plastic lid for reducing water losses during incubation. 
The containers $(n=24)$ were kept for $24 \mathrm{~h}$ in an acclimatized chamber $\left(15{ }^{\circ} \mathrm{C}\right.$ and dark) for equilibration. During this time, adults and clitellated earthworms $(n=72)$ were placed in Petri dishes, kept at $15^{\circ} \mathrm{C}$ and dark to allow gut voiding, and then the body weight was recorded ( $t=0 \mathrm{wk})$. Once earthworms were weighted, they were released in the containers according to the experimental groups (lowand high-density treatments), and the containers were incubated for 18 wk. Earthworms were periodically fed with $1 \mathrm{~g}$ of $M$. alba litter per individuals, which was added on soil surface. The impact of food addition on soil enzyme activities was assessed with the litter treatment. In this experimental treatment, an amount of $8 \mathrm{~g}$ of litter were mixed manually in the bulk soil of each replicate, which corresponded to the maximum charge of food in the high-density treatment.

Periodically ( $t=1,2,6,12$ and $18 w \mathrm{w}$ ), a soil subsample was taken from each replicate and treatment. Firstly, soil of each test container was placed in individual plastic trays and, in the case of the low- and high-density treatments, the earthworms were transferred to Petri dishes previously marked according to each replicate and treatment. Secondly, the bulk soil was homogenized using a spatula, and a subsample $(\sim 10 \mathrm{~g})$ was taken for further determination of chlorpyrifos concentration as well as for biochemical analysis. At the same time, the earthworms were kept in Petri dishes for $24 \mathrm{~h}$ at $15^{\circ} \mathrm{C}$ and dark to collect casts and record the body weight. Finally, we returned earthworms to the corresponding replicates and placed the containers in the acclimatized chamber up to the next sampling time. Determination of soil enzyme activities at $t=0 \mathrm{wk}$. corresponded to soil subsamples taken before chlorpyrifos application.

\subsection{Physicochemical properties of soil and chlorpyrifos residues}

Total organic $\mathrm{C}, \mathrm{pH}$ and electrical conductivity were determined in soils (sieved to pass a 2-mm mesh) before applying either chlorpyrifos, earthworms or litter ( $t=0 \mathrm{wk})$, and 1 and $18 \mathrm{wk}$. after spiking the soil with the pesticide. Organic carbon was determined according to the dichromate redox colorimetric method by Skjemstad and Baldock (2008), using sucrose $\left(0-16 \mathrm{mg} \mathrm{C} \mathrm{ml}^{-1}\right)$ as the standard. Electrical conductivity and $\mathrm{pH}$ were determined with suitable electrodes in soil:water suspensions $(1: 5, \mathrm{w} / \mathrm{v})$, where the soil had been previously dried $\left(105^{\circ} \mathrm{C}, 48 \mathrm{~h}\right)$. Chlorpyrifos was extracted from soils and earthworm casts using the QuEChERS (Quick, Easy, Cheap, Effective, Rugged and Safe) method, and quantified by HPLC as described in Sanchez-Hernandez et al. (2017) (see Supplementary Information for details).

\subsection{Earthworm biomarkers}

We selected biomarkers linked to the mode of toxic action of organophosphorus pesticides. Thus, the inhibition of acetylcholinesterase (AChE, EC 3.1.1.7) and carboxylesterase (CbE, EC 3.1.1.1) activities was used as indicator of chlorpyrifos exposure and toxicity. The former is the primary target for organophosphorus acute toxicity (Fukuto, 1990), whereas the latter participates in the detoxification of these compounds through phosphorylation of the active site of the enzyme by the oxon metabolite of organophosphorus (Sogorb and Vilanova, 2002). Furthermore, because the metabolism of organophosphorus pesticides may cause oxidative stress (Lukaszewicz-Hussain, 2010), some biomarkers of oxidative status (i.e., glutathione-dependent enzymes and total antioxidant capacity) and oxidative damage (lipid peroxidation) were also part of this study.

All biomarkers were measured in homogenates obtained from the wall muscle tissue because it is a major route for contaminant uptake (Jager et al., 2003). We used only eight earthworms per treatment to measure biomarker responses after 18 wk of chlorpyrifos exposure. The earthworms were chosen randomly from the six replicates of each experimental treatment (low- and high-density treatments). A group of non-exposed earthworms (reference group, $n=8$ ), which were subjected to the same experimental conditions than chlorpyrifos-exposed earthworms, served to compare biomarker responses with those exposed to the pesticide. This sample size of 8 individuals per treatment was estimated using the $G^{*}$ Power software (www.gpower.hhu.de) with a significance level of $\alpha=0.05$ at 0.8 power, and effect size values ranging between 0.34 and 2.41 that were calculated from data on $\mathrm{AChE}$ and CbE activities previously published (Supplementary Table 2 in Collange et al., 2010). Wall muscle tissues were carefully removed, water rinsed and homogenized $(1: 10, \mathrm{w} / \mathrm{v})$ in ice-cooled $20 \mathrm{mM}$ Tris- $\mathrm{HCl}$ buffer $(\mathrm{pH}=7.6$ ) containing $1 \mathrm{mM}$ EDTA, using a glassPTFE Potter-Elvehjem tissue grinder. The homogenates were centrifuged $\left(9000 \times \mathrm{g}, 4^{\circ} \mathrm{C}, 20 \mathrm{~min}\right)$, and the post-mitochondrial fraction (total protein concentration $=51.8 \pm 10.5 \mathrm{mg} \mathrm{g}^{-1}$ muscle tissue, $n=24$ samples) was collected for biomarker analysis.

Acetylcholinesterase activity was determined according to the microplate-scale spectrophotometric assay described in Wheelock et al. (2005), whereas CbE activity was assayed following the method by Thompson (1999) and using two naphthyl esters as substrates (1naphthyl acetate [1-NA] and 1-naphthyl butyrate [1-NB]). We used two substrates because of the occurrence of multiple CbE isozymes with marked sensitivity towards organophosphorus exposure (Wheelock et al., 2008). Glutathione reductase (GR, EC 1.6.4.2) activity was determined according to the procedure described in RamosMartinez et al. (1983). The measurement of cumene hydroperoxide-dependent glutathione peroxidase (GPX, EC 1.11.1.9) activity followed the method by Lawrence and Burk (1976). Total antioxidant capacity (TAC) was determined by the microplate-scale colorimetric method by Erel (2004). Lipid peroxidation was measured according to the chromatographic method by Agarwal and Chase (2002). A full description of these biomarker procedures is provided in the Supplementary Information.

\subsection{Soil enzyme activities}

The potential activity of acid phosphatase, alkaline phosphatase, $\beta$ glucosidase, dehydrogenase and $\mathrm{CbE}$ was used as a biological indicator of soil quality (Paz-Ferreiro and Fu, 2013). Although enzymes exist in soil as both intracellular (associated to viable cells) and extracellular (associated to soil organomineral complexes) forms, the latter provide a significant amount of the total enzyme activity of soil (Dick et al., 1997; Shaw and Burns, 2006; Nannipieri, 2006). Therefore, the measurement of phosphatase, $\beta$-glucosidase and $\mathrm{CbE}$ activities may be considered due to extracellular enzymes, whose activity is no longer associated to viable cells. However, dehydrogenase activity exists in soil as part of the oxidative processes occurring within living cells, so its measurement reflects intracellular enzyme solely and, therefore, it is considered a direct indicator of microbial activity (von Mersi and Schinner, 1991; Shaw and Burns, 2006). In this study, we have measured these soil enzyme activities using soil-water suspensions, so the observed activity reflects those of both intracellular and extracellular enzymes.

Soil- and cast-water suspensions were prepared as described in Sanchez-Hernandez et al. (2017), with slight modifications. One gram of wet soil, or $0.5 \mathrm{~g}$ of fresh cast $(<24 \mathrm{~h}$ old $)$, was dispersed in distilled water $(1: 50, \mathrm{w} / \mathrm{v})$ and agitated for $30 \mathrm{~min}$ at room temperature $\left(\sim 20^{\circ} \mathrm{C}\right)$ using an orbital shaker. This procedure was compatible with a high-throughput microplate-scale assays for each enzyme activity. Thus, aliquots of these suspensions were poured in 96-well bottom-flat microplates containing the corresponding substrates and buffers for measuring the activity of phosphatases ( $4 \mathrm{mM}$ of 4-nitrophenyl phosphate in $20 \mathrm{mM}$ modified universal buffer [MUB] adjusted at $\mathrm{pH}=6.5$ for acid phosphatase and $\mathrm{pH}=11.0$ for alkaline phosphatase), $\beta$-glucosidase ( $4 \mathrm{mM} 4$-nitrophenyl $\beta$-D-glucanopyranoside in $20 \mathrm{mM}$ MUB, $\mathrm{pH}=7.4)$, and $\mathrm{CbE}(2 \mathrm{mM} 1-\mathrm{NB}$ in $0.1 \mathrm{M}$ Tris- $\mathrm{HCl}$ $\mathrm{pH}=7.4)$. Enzyme activities were expressed as $\mu \mathrm{mol}$ of product (1-naphthol or 4-nitrophenolate) per hour and gram of dry mass, using calibration curves made with 1-naphthol or 4-nitrophenolate, 
and in the presence of the sample to correct the adsorption of chromogenic substances to soil colloids. Controls (substrate-free) and blanks (soil-free) were used to correct the background absorbance and non-enzymatic hydrolysis of the substrates, respectively. The activity of dehydrogenase was measured according to von Mersi and Schinner (1991), and the reaction medium consisted of the substrate iodonitrotetrazolium chloride, Tris- $\mathrm{HCl} 1 \mathrm{M}(\mathrm{pH}=7.0)$ and the sample ( $0.5 \mathrm{~g}$ of wet soil, or $0.2 \mathrm{~g}$ of wet cast). The product of this reaction (iodonitrotetrazolium formazan) was determined spectrophotometrically at $464 \mathrm{~nm}$ after 1 -h reaction at $40{ }^{\circ} \mathrm{C}$, and the results were expressed as $\mu \mathrm{mol}$ of product $\mathrm{h}^{-1} \mathrm{~g}^{-1}$ dry soil. A detailed description of soil enzyme assays is provided in the Supplementary Information.

\subsection{Data analysis}

The impact of chlorpyrifos on earthworm weight, soil and cast enzyme activities, and enzymatic indexes was assessed using a repeatedmeasures ANOVA test. The assumption of sphericity was checked using the Mauchly's test and, in case of failure $(P>0.05)$, the degrees of freedom associated to the obtained $F$-ratio were estimated using the Greenhouse-Geisser correction. Comparisons of soil physicochemical properties were performed with the Kruskall-Wallis test followed by the post-hoc Mann-Whitney's U test.
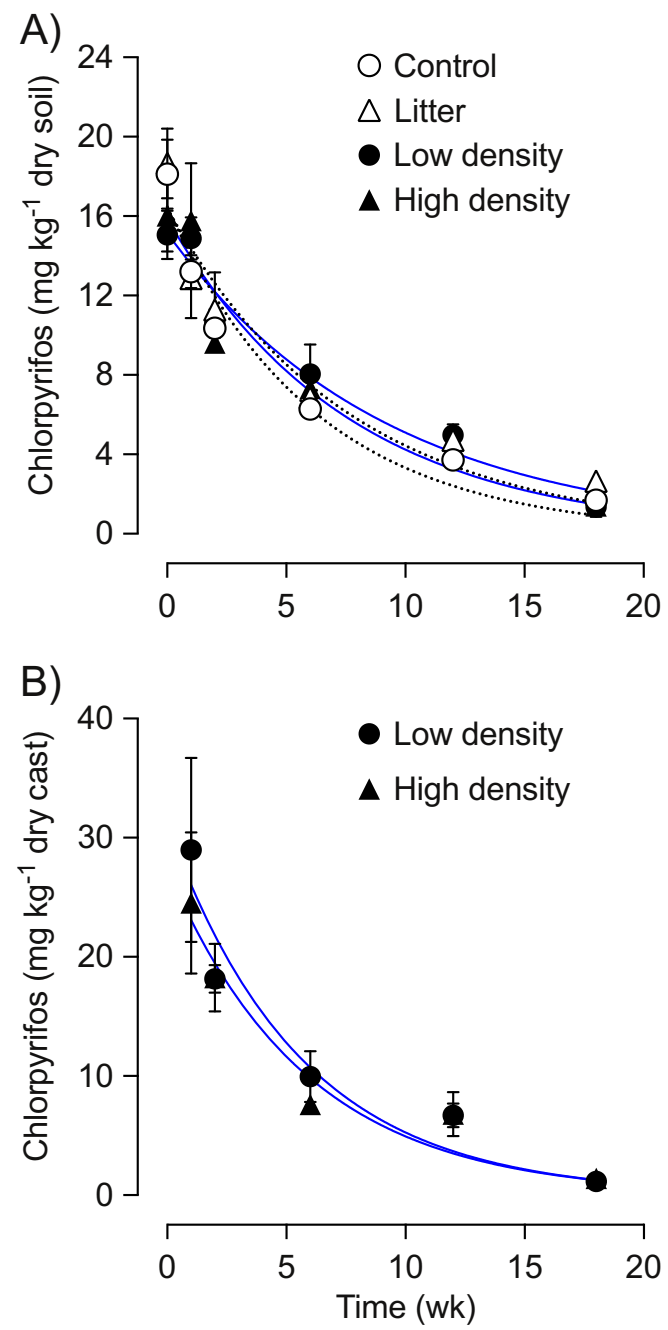

Fig. 1. A) Degradation kinetics of chlorpyrifos in soil during $18 \mathrm{wk}$ of incubation; see Table 1 for treatments. B) Concentrations of chlorpyrifos in casts $(<24-h$ old $)$ periodically sampled from earthworms incubated for 18 wk in chlorpyrifoscontaminated soils. Kinetic parameters are summarized in Table 1. Symbols represent the mean and standard deviation $(n=6)$.
The 'Integrated Biomarker Response, version 2' (IBRv2) index proposed by Sanchez et al. (2013) was used to assess the impact of longterm chlorpyrifos exposure on the status health of earthworms. This index was calculated using the biomarkers AChE, CbE, GR, GPx, TAC and lipid peroxidation, according to the following equation:

$I B R v 2=\sum|A|$

where $A$ represents a deviation index for each biomarker respect to a reference value (reference group). This response deviation parameter was calculated as follows:

$A=\left(\frac{\log \left(\frac{X_{i}}{X_{0}}\right)-\mu}{\sigma}\right)-Z_{0}$

For each biomarker, data $\left(X_{i}\right)$ were compared to the mean value obtained from the reference earthworm group $\left(X_{0}\right)$, and logarithmically transformed to minimize the variance (Sanchez et al., 2013). The next step involved the standardization of these log-transformed data considering the general mean $(\mu)$ and standard deviation $(\sigma)$. Finally, the mean of the standardized biomarker data was subtracted from the mean of the reference standardized data $\left(Z_{0}\right)$, and the biomarker deviation index $(A)$ was obtained. The $A$ parameters were plotted in a star plot that allowed to assess an induction (the area up to 0 ) or inhibition (area down to 0) response of biomarkers (Sanchez et al., 2013).

The impact of earthworms on soil enzyme activities was assessed using two common enzymatic indexes in soil biochemistry: the geometric mean (GMean) index (Hinojosa et al., 2004), and the treatedsoil quality index (T-SQI) proposed by Mijangos et al. (2010). The GMean index was calculated as follows:

GMean $=\left(\prod_{i=1}^{n} y_{i}\right)^{1 / n}$

where $y_{\mathrm{i}}$ is the enzyme activity, $n$ is the total number of soil enzymes. High GMean values mean high microbial funcional diversity of soil (Lessard et al., 2014).

The T-QSI was calculated using the following equation:

$\mathrm{T}-\mathrm{SQI}=10^{\log m+\frac{\sum_{i=1}^{n}\left(\log n_{i}-\log m\right)-\sum_{i=1}^{n}\left|\log _{i}-\log \bar{n}\right|}{n}}$

where $m$ is the reference soil (mean value of enzyme activity, set to $100 \%)$, and $n$ is the mean value for each enzyme activity in earthworm-treated soils as percentages of the reference soil. The T-SQI measures the magnitude and direction (increase or inhibition) of changes caused by an environmental stressor (e.g., organic amendments or environmental contaminants) on soil enzyme activities compared with those from a reference soil (Mijangos et al., 2010).

Table 1

Kinetic parameters for chlorpyrifos dissipation in bulk soil and earthworm casts.

\begin{tabular}{lllll}
\hline Sample & Treatment $^{\mathrm{a}}$ & $C_{o}\left(\mathrm{mg} \mathrm{kg}^{-1}\right)$ & $k\left(\mathrm{~d}^{-1}\right)$ & $t_{1 / 2}(\mathrm{~d})$ \\
\hline \multirow{2}{*}{ Soil } & Control & $16.4 \pm 1.10$ & $0.023 \pm 0.004$ & 30.3 \\
& Litter & $16.3 \pm 1.29$ & $0.018 \pm 0.004$ & 37.1 \\
& Low density & $15.1 \pm 0.83$ & $0.015 \pm 0.002$ & 44.5 \\
\multirow{3}{*}{ Casts } & High density & $15.8 \pm 1.21$ & $0.019 \pm 0.004$ & 36.7 \\
& Low density & $31.1 \pm 4.12$ & $0.025 \pm 0.007$ & 27.3 \\
& High density & $27.4 \pm 3.14$ & $0.025 \pm 0.006$ & 28.2 \\
\hline
\end{tabular}

a Control = earthworm- and litter-free soils, Litter = earthworm-free soils amended with litter, Low density = soils inoculated with two earthworms $\mathrm{kg}^{-1}$ wet soil, and High density $=$ soils inoculated with four earthworms $\mathrm{kg}^{-1}$ wet soil. 
Table 2

Mean $( \pm$ SD, $\mathrm{n}=6)$ values of selected physicochemical variables of test soils before $(t=0 \mathrm{wk})$ and after treatment with 20 mg chlorpyrifos $\mathrm{kg}^{-1}$ wet soil.

\begin{tabular}{|c|c|c|c|c|}
\hline Time (weeks) & Treatment $^{\mathrm{a}}$ & $\mathrm{pH}$ & E.C. $\left(\mu \mathrm{Sm}^{-1}\right)$ & Total organic carbon ( $\mathrm{mg} \mathrm{C}^{-1}$ dry soil) \\
\hline 0 & Reference & $8.17 \pm 0.06$ & $113.5 \pm 5.0$ & $5.28 \pm 0.21$ \\
\hline \multirow[t]{4}{*}{1} & Control & $8.42 \pm 0.08^{\mathrm{a}}\left(^{*}\right)$ & $100.8 \pm 17.7^{\mathrm{a}}$ & $5.17 \pm 0.46^{\mathrm{a}}\left(^{*}\right)$ \\
\hline & Litter & $8.40 \pm 0.06^{\mathrm{a}}\left(^{*}\right)$ & $91.5 \pm 1.20^{\mathrm{a}}\left(^{*}\right)$ & $5.01 \pm 0.25^{\mathrm{a}}\left(^{*}\right)$ \\
\hline & Low density & $8.12 \pm 0.10^{a}$ & $120 \pm 22.7^{a}$ & $4.92 \pm 0.78^{a}$ \\
\hline & High density & $8.37 \pm 0.11^{\mathrm{a}}\left({ }^{*}\right)$ & $98.7 \pm 6.0^{\mathrm{a}}\left({ }^{*}\right)$ & $5.00 \pm 0.52^{\mathrm{a}}$ \\
\hline \multirow{4}{*}{18} & Control & $8.24 \pm 0.16^{\mathrm{b}}$ & $121.8 \pm 25.6^{\mathrm{a}}$ & $5.72 \pm 0.58^{\mathrm{a}}\left({ }^{*}\right)$ \\
\hline & Litter & $8.17 \pm 0.05^{\mathrm{b}}$ & $134.4 \pm 22.0^{\mathrm{b}}\left(^{*}\right)$ & $7.42 \pm 0.16^{\mathrm{b}}\left(^{*}\right)$ \\
\hline & Low density & $7.94 \pm 0.15^{\mathrm{a}}\left(^{*}\right)$ & $234.1 \pm 8.4^{\mathrm{b}}\left(^{*}\right)$ & $8.27 \pm 0.61^{\mathrm{b}}\left(^{*}\right)$ \\
\hline & High density & $7.87 \pm 0.07^{\mathrm{b}}\left({ }^{*}\right)$ & $256.6 \pm 24.5^{\mathrm{b}}\left(^{*}\right)$ & $9.13 \pm 0.77^{\mathrm{b}}\left({ }^{*}\right)$ \\
\hline
\end{tabular}

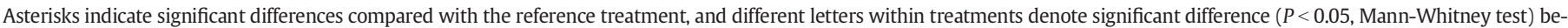
tween sampling times ( 1 and $18 \mathrm{wk}$ ).

a Treatments as in Table 1. Reference treatment corresponded to uncontaminated soil.

Chlorpyrifos dissipation in soil and casts was assessed by a simple exponential decay model (Hernández-Soriano et al., 2009):

$C=C_{0} \times e^{-k t}$

where $C$ is the concentration of chlorpyrifos $\left(\mathrm{mg} \mathrm{kg}^{-1}\right)$ at time $t(\mathrm{~d})$ after being applied to the soil, $C_{0}$ is the initial concentration ( $\left.\mathrm{mg} \mathrm{kg}^{-1}\right)$ and $k\left(\mathrm{~d}^{-1}\right)$ is the degradation rate constant. The half-life $\left(t_{1 / 2}\right)$ of chlorpyrifos was calculated according to the equation:

$t_{1 / 2}=\frac{\operatorname{Ln} 2}{k}$

\section{Results and discussion}

\subsection{Impact of earthworms on chlorpyrifos persistence in soil}

Chlorpyrifos dissipation rate was fitted to a first-order kinetic model in all the treatments (Fig. 1A). Half-life times $\left(t_{1 / 2}\right)$ in control soils were slightly lower than in litter-amended or earthworm-treated soils (Table 1). Nevertheless, these half-life times were within the range of variation reported elsewhere in loam and sandy loam, moderately alkaline $(\mathrm{pH}=7.8-8.5)$ soils, which range between 17 and $85 \mathrm{~d}$ (Racke et al., 1996). Chlorpyrifos residues were also determined in earthworm casts to evidence exposure via ingestion of contaminated soil (Fig. 1B). The data from these samples confirmed the first-order degradation kinetics found in soils, with no substantial differences between both of earthworm density groups, and between the $t_{1 / 2}$ values measured in soil and casts (Table 1). However, casts had higher initial chlorpyrifos concentrations as compared with the bulk soil (Fig. 1B), probably because this material is enriched in organic matter and clay/silt particles that adsorb chlorpyrifos (Yu et al., 2006).

However, and unexpectedly, earthworm activity did not enhance chlorpyrifos degradation rate compared with the control treatment. A possible explanation for this might come from the partitive properties of chlorpyrifos. This chemical has a high sorption partition coefficient between soil organic $C$ and the soil solution $\left(\log K_{\mathrm{OC}}=3.70-4.13\right.$, Mackay et al., 2006), which suggests that sorption of chlorpyrifos to soil organic matter could difficulty biodegradation because of limited accessibility and bioavailability (Megharaj et al., 2011). Although in our experiments organic matter was applied as fresh, non-humified litter, earthworms effectively incorporated it to the bulk soil, as shown by the significant increase in soil organic $\mathrm{C}$ after the 18 -wk incubation time (Table 2), thus increasing the probability of pesticide-sorption reactions. This fact, however, was not entirely dependent on earthworm activity, as organic $C$ in litter-amended soils also increased (Mann-Whitney test, $P<0.05)$ compared with control soils.

Despite it is generally assumed that earthworm activity promotes degradation of environmental contaminants (Hickman and Reid, 2008; Rodriguez-Campos et al., 2014; Martinkosky et al., 2017), some authors question this environmental service. In fact, earthworm casts can be a sink for environmental contaminants with moderate to high sorption partitioning coefficients (Shan et al., 2011). The higher content
A)

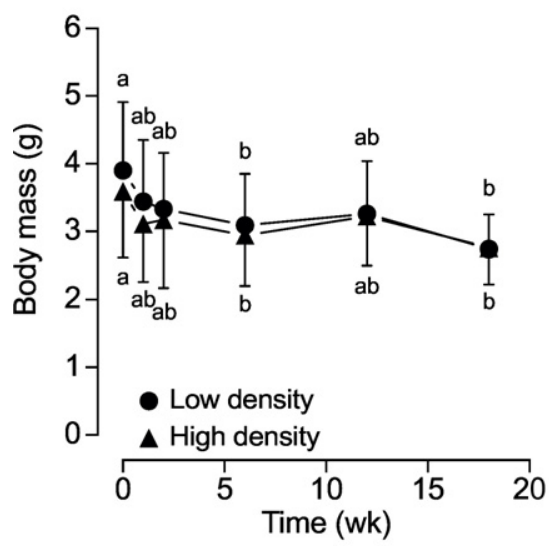

B)

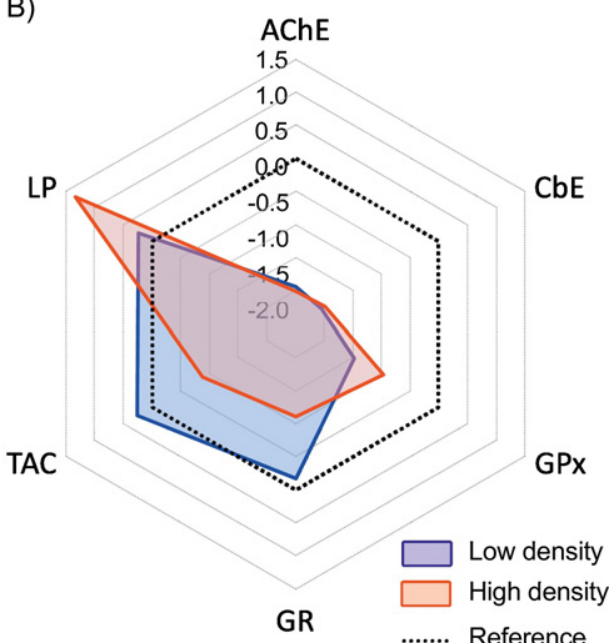

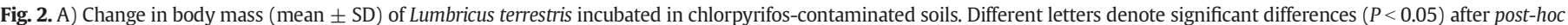

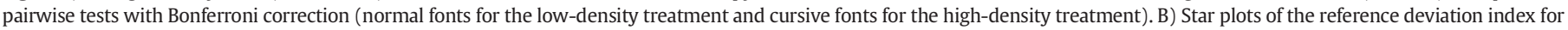

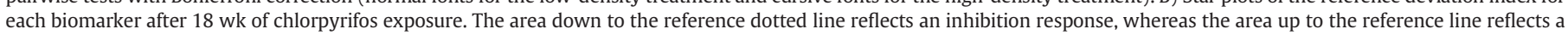
biomarker induction (see Table 3 for biomarker abbreviations). 
in fine mineral particles (clay and silt) and organic matter (e.g., mucus) present in casts, as compared with the bulk soil, leads to accept that earthworm activity enhances contaminant persistence in soil instead of accelerating its degradation (Bolan and Baskaran, 1996). Our results support this latter hypothesis, and suggest that feeding and casting activities by $L$. terrestris contributed to disperse organic matter in the whole soil, so increasing chlorpyrifos persistence.

\subsection{Impact of chlorpyrifos exposure on Lumbricus terrestris}

No earthworm mortality was recorded during the microcosm study, although the mean body weight slightly decreased (23.0-29.6\% respect to values recorded at $t=0 \mathrm{wk}$ ) by the end of the incubation time in the low-density $\left(F_{3.1,67.7}=3.56, P=0.018\right)$ and the high-density group $\left(F_{4.1,181}=4.15, P=0.003\right)$ (Fig. $\left.2 \mathrm{~A}\right)$. These percentages of weight loss matched, however, the criteria $(<30 \%$ weight loss in long-term experiments) established for control earthworms in order to accept experimental results as valid (Fründ et al., 2010). Chlorpyrifos concentration in our study was sublethal ( $20 \mathrm{mg}$ chlorpyrifos $\mathrm{kg}^{-1}$ wet soil), as median lethal concentration at $14 \mathrm{~d}$ for $L$. terrestris has been estimated to be around $458 \mathrm{mg} \mathrm{kg}^{-1}$ (403-521, 95\% confidence interval) in artificial soil (Ma and Bodt, 1993), so in our experiment a high survival percentage was reasonably expected. However, the response of the biomarkers measured in earthworm muscle revealed that: i) chlorpyrifos caused a strong inhibition of both AChE and CbE activities (91-94\% compared to the reference group) after $18 \mathrm{wk}$ of pesticide treatment (Table 3 ), ii) long-term exposure to chlorpyrifos seemed to have induced oxidative stress with a significant decrease of GPx activity and GR activity, and an increase of lipid peroxidation; although the response of the two latter biomarkers was statistically significant in the high-density treatment.

The response of $\mathrm{AChE}$ and $\mathrm{CbE}$ activities was not surprising as these esterases are sensitive to inhibition by organophosphorus pesticides. Furthermore, they often display a slow recovery rate of their activity after inhibition (Rault et al., 2008; Collange et al., 2010; Velki and Hackenberger, 2013; Muangphra et al., 2015). However, most of these studies did not cover more than one month of monitoring period for activity recovery. In our study, inhibition $>90 \%$ of the mean reference activity were still observed after $18 \mathrm{wk}$. of pesticide application, despite residues of chlorpyrifos at this time had decreased up to $1.35 \pm 0.27 \mathrm{mg} \mathrm{kg}^{-1}$ dry soil (low-density treatment) and $1.40 \pm$ $0.55 \mathrm{mg} \mathrm{kg}^{-1}$ dry soil (high-density treatment). This observation suggests not only an extremely slow recovery of AChE and CbE activities for this earthworm species compared with others (Rault et al., 2008; Velki and Hackenberger, 2013), but also the presence of chlorpyrifosoxon in the earthworm muscle able to inhibit newly synthesized enzyme. Although we did not measure chlorpyrifos concentration in the earthworm body, a related study by Collange et al. (2010) using

Table 3

Mean $( \pm \mathrm{SD}, n=8)$ biomarker responses in the muscle tissue of Lumbricus terrestris after $18 \mathrm{wk}$ of a single treatment of soil with chlorpyrifos $\left(20 \mathrm{mg}\right.$ active ingredient $\mathrm{kg}^{-1}$ wet soil).

\begin{tabular}{llll}
\hline Biomarkers $^{\mathrm{a}}$ & \multicolumn{2}{l}{ Experimental groups } \\
\cline { 2 - 4 } & Reference & Low density & High density \\
\hline AChE activity (nmol/min/mg protein) & $196.7 \pm 59.2$ & $16.67 \pm 4.01^{*}$ & $16.73 \pm 6.97^{*}$ \\
CbE activity (nmol/min/mg protein) & $117.3 \pm 38.9$ & $6.27 \pm 2.74^{*}$ & $6.43 \pm 1.50^{*}$ \\
GR activity (nmol/min/mg protein) & $8.14 \pm 1.78$ & $8.07 \pm 3.02$ & $5.47 \pm 2.12^{*}$ \\
GPx activity (nmol min/mg protein) & $9.96 \pm 2.58$ & $5.31 \pm 2.75^{*}$ & $6.17 \pm 1.86^{*}$ \\
TAC (nmol Trolox equiv./mg protein) & $33.58 \pm 5.85$ & $36.00 \pm 7.91$ & $27.38 \pm 7.46$ \\
LP (nmol malondyaldehide/mg & $1.52 \pm 0.49$ & $1.77 \pm 0.60$ & $3.96 \pm 2.85^{*}$ \\
protein) & & & \\
\hline
\end{tabular}

${ }^{\mathrm{a}} \mathrm{AChE}=$ Acetylcholinesterase, $\mathrm{CbE}=$ Carboxylesterase, $\mathrm{GR}=$ Glutathione reductase, GPx = Cumene hydroperoxide-dependent glutathione peroxidase, TAC = Total antioxidant capacity, LP = Lipid peroxidation.

* Significant differences compared with the reference group (Mann-Whitney test, $P<0.05)$. chlorpyrifos-exposed L. terrestris, demonstrated that residues of chlorpyrifos-oxon were still present in earthworm muscle after $35 \mathrm{~d}$ of a recovery period. These authors confirmed the presence of the toxic metabolite by incubation of a commercial electric eel type V-S AChE solution (Sigma-Aldrich, Madrid, Spain) in the presence of filtered homogenates (free of earthworm ChEs) obtained from the muscle of $L$. terrestris exposed for $2 \mathrm{~d}$ to soils contaminated with 3 and $12 \mathrm{mg} \mathrm{kg}^{-1}$ chlorpyrifos. The eel AChE activity was inhibited by $21-64 \%$ of control samples demonstrating the presence of chlorpyrifos-oxon. These data support our hypothesis that inhibition of esterase activities in our earthworms could be due to significant concentrations of chlorpyrifos-oxon in muscle tissue.

We used the IBRv2 index as an integrated measurement of biomarkers to evidence a density-dependent toxicity from chlorpyrifos exposure. Higher IBRv2 values are generally reported in animals inhabiting contaminated sites compared with individuals from uncontaminated environments (Vieira et al., 2016). However, the values calculated for both earthworm groups in our study were very similar to each other (IBRv2 $=5.15$ for the low-density treatment and 5.67 for the high-density treatment), which was not surprising if we take into account that exposure to the pesticide during the full incubation period was similar between both groups as shown by the dissipation rates of
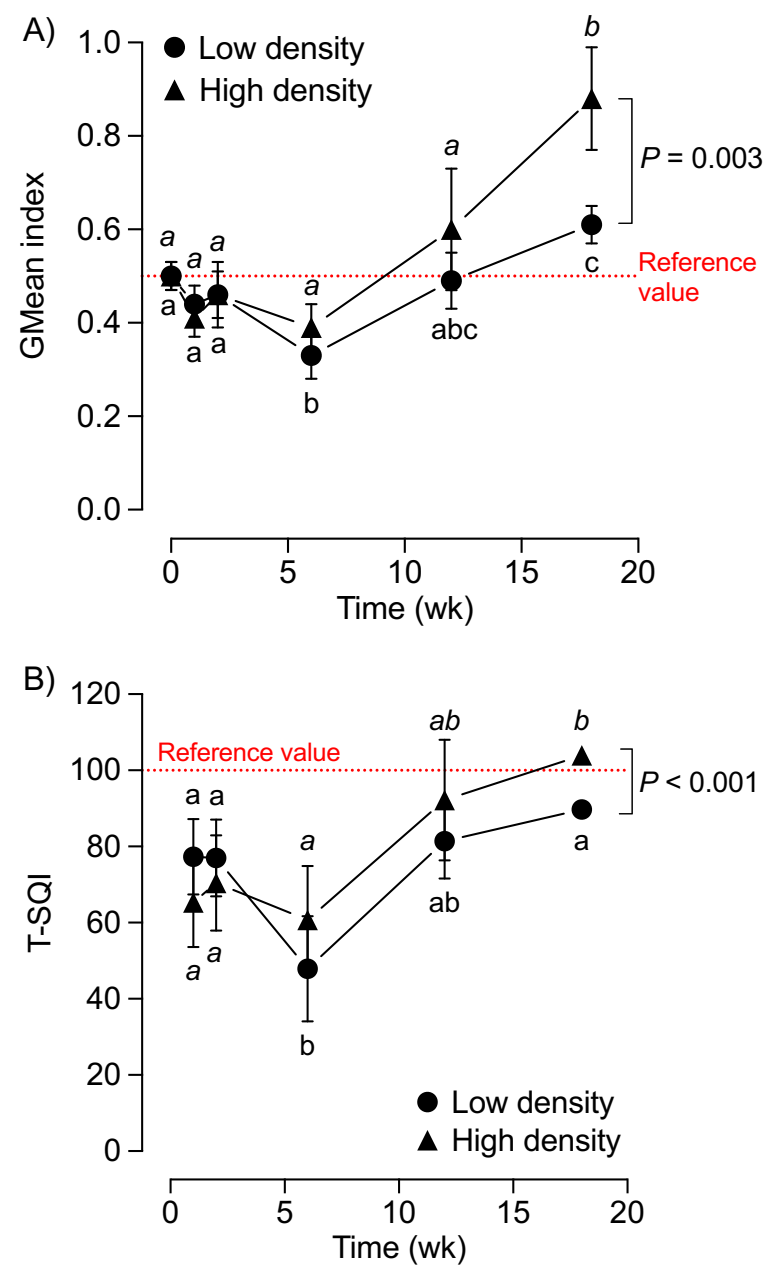

Fig. 3. Mean $( \pm S D, n=6$ ) values of the geometric mean (GMean, graph $A$ ) index and treated-soil quality index (T-SQI, graph B) for soil enzyme activities of chlorpyrifoscontaminated soils inoculated with two earthworms $\mathrm{kg}^{-1}$ wet soil (low-density treatment) and four earthworms $\mathrm{kg}^{-1}$ wet soil (high-density treatment). Different letters denote significant differences $(P<0.05)$ after post-hoc pairwise tests with Bonferroni correction (normal fonts for the low-density treatment and cursive fonts for the high-density treatment). Dotted horizontal line denotes the reference value of both enzymatic indexes for the chlorpyrifos-free soil (reference soil). 
chlorpyrifos in both experimental treatments. Likewise, the algorithm for the IBRv2 calculation also provides the called 'response deviation index' $(A)$ for each biomarker respect to the reference group. These scores allow easily to discriminate between induction and inhibition for each biomarker (Sanchez et al., 2013). In our study, despite the IBRv2 values were closely similar for both earthworm groups, the star plot generated with the $A$-scores revealed that signs of oxidative stress were more evident in the high-density group than in the low-density group (Fig. 2B). There was a marked inhibition of the activity of glutathione-dependent antioxidant enzymes in concomitance with a lower antioxidant capacity of the tissue in the high-density group. This reduced enzymatic and molecular capability for removing free radicals could lead to oxidative damage. In fact, lipid peroxidation was significantly higher in this earthworm group compared with that of low-density treatment. In the light of this finding, factors other than chlorpyrifos exposure, such as the individual density in the microcosm, could trigger oxidative stress. For example, it has been reported that a high density of $L$. terrestris under laboratory conditions has a significant negative impact on the life cycle traits of this species (Lowe and Butt, 2005).

Although the use of the IBRv2 is gaining popularity in the environmental risk assessment of pollutant in the aquatic system, our study together with that by Bonnail et al. (2016) are an example that this algorithm is also a suitable tool in laboratory toxicity testing to assess sublethal impact from contaminant exposure using sub-individual biomarkers.

\subsection{Soil enzyme dynamics}

We used two enzymatic indexes, i.e., GMean and T-SQI, to evaluate the effect of chlorpyrifos on the global response of soil enzyme activities. There was a significant main effect of time on soil enzyme activities evidenced by the GMean index $\left(F_{1.9,9.7}=75.1, P<0.0001\right.$, partial $\eta^{2}=$
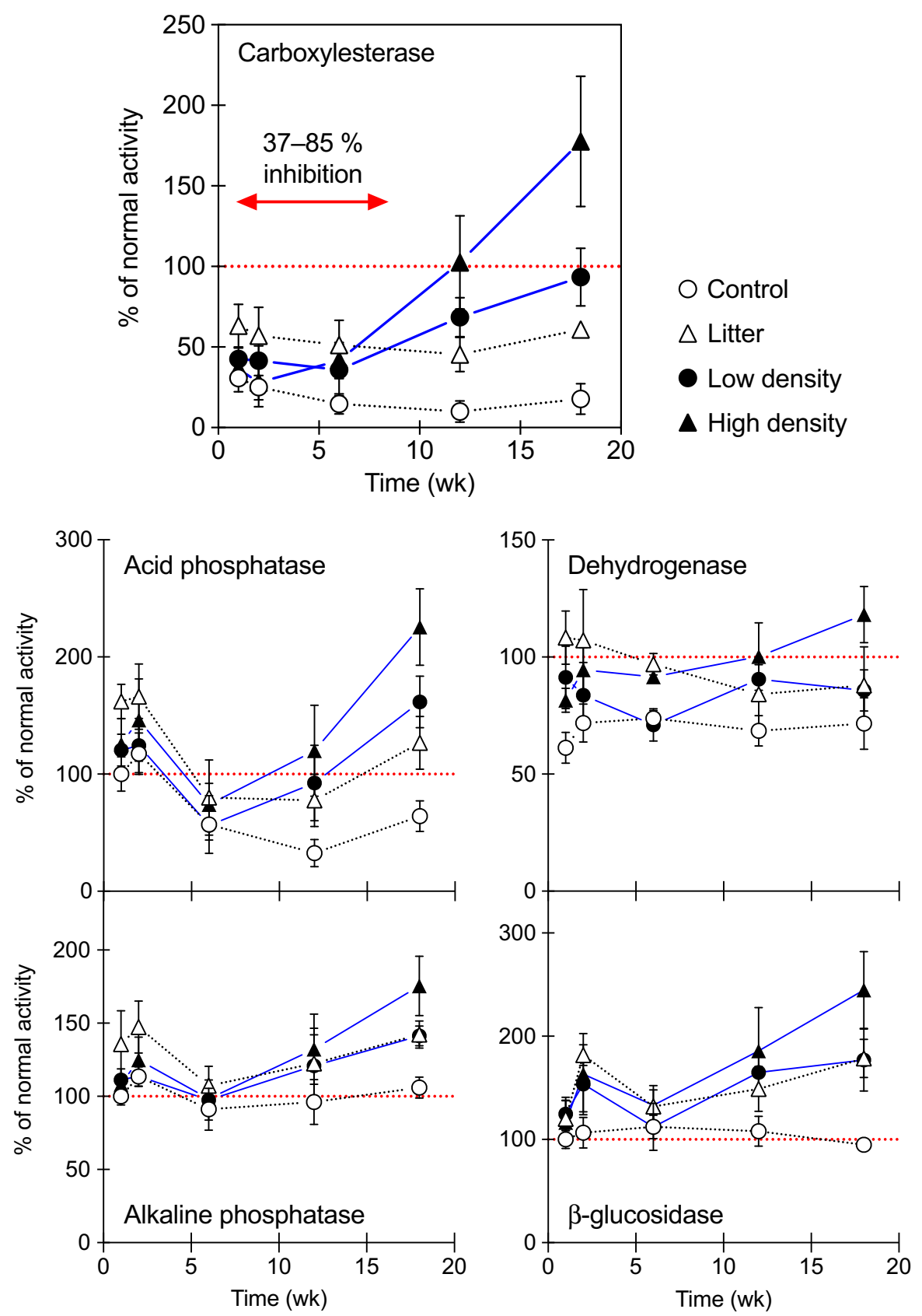

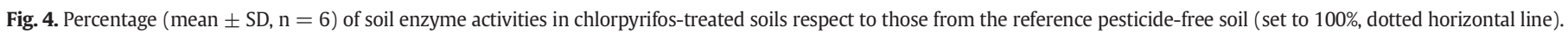
Treatments as in Table 1. 
$0.94)$ and the T-SQI $\left(F_{4,20}=35.3, P<0.0001\right.$, partial $\left.\eta^{2}=0.87\right)$. Both indexes showed that chlorpyrifos decreased the global enzyme response after 6 wk. of exposure compared to the reference values (Fig. $3 \mathrm{~A}$ and B). However, the presence of earthworms caused a progressive recovery of soil enzyme activities, even surpassing the basal levels of activity in the following weeks. Moreover, this recovery was significantly influenced by the density of earthworms $\left(F_{5,25}=8.40, P<0.0001\right.$, partial $\eta^{2}=0.63$ for the GMean index, and $F_{4,20}=2.91, P=0.048$, partial $\eta^{2}$ $=0.37$ for the T-SQI), being faster and leading to higher levels of enzyme activity in the high-density treatment $(P \leq 0.003)$. Enzymebased indexes are common tools in the assessment of pollutant impact on soil biochemical performance (Puglisi et al., 2006; Paz-Ferreiro and Fu, 2013). Particularly, the GMean index has been satisfactorily used to assess soil quality in metal-contaminated soils (Hinojosa et al., 2004; Lessard et al., 2014), oil-contaminated saline soils (Gao et al., 2013), contrasting agricultural managements (Paz-Ferreiro et al.,
2014), as well as in the evaluation of the effectiveness of bioremediation actions in metal-contaminated soils (Lu et al., 2015). Similarly, the T-SQI has been used to examine the impact of pesticide and fertilizer inputs on several microbial indicators of soil quality (Muñoz-Leoz et al., 2013). The results of our study extend the suitability of these two enzymatic indexes to laboratory toxicity testing.

However, and despite the usefulness of these enzymatic indexes, individual enzyme responses to chlorpyrifos should be carefully examined to identify the most sensitive soil enzyme activities. In our study, time of chlorpyrifos exposure, treatment of soils with earthworms and litter, as well as the interaction between these two independent variables caused a significant impact on all enzyme activities (Supplementary Table S1). Nevertheless, only CbE activity was severely inhibited by chlorpyrifos (37-85\% of controls) in all treatment groups in the first six weeks following the acute treatment (Fig. 4). An effect, however, not observed for the other three hydrolases. In fact, the activity of
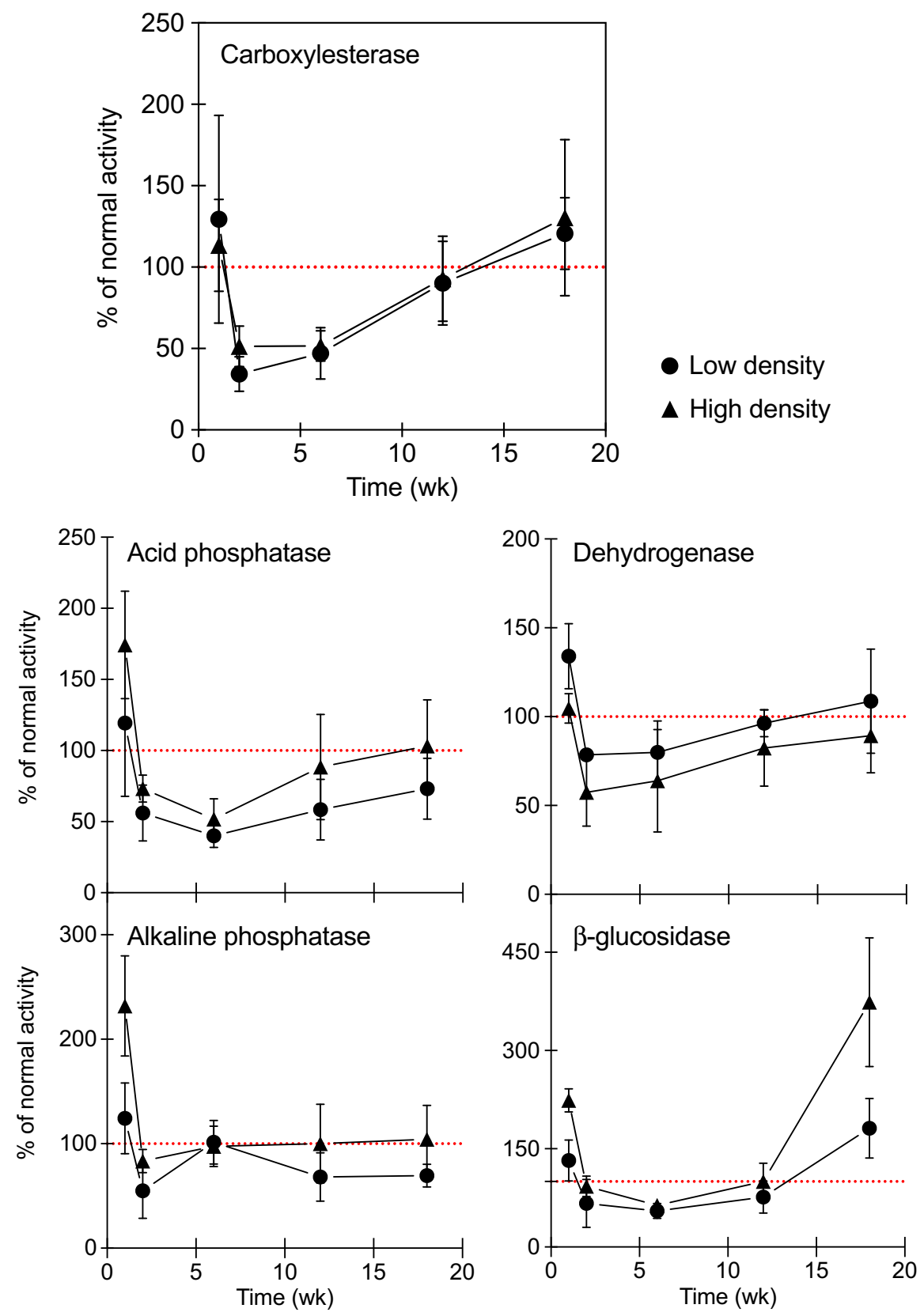

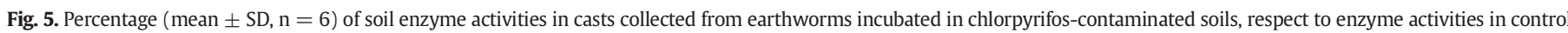
casts (set to $100 \%$, dotted horizontal line). Treatments as in Table 1 . 
phosphatases and $\beta$-glucosidase was similar or even higher than that measured in chlorpyrifos-free soils during this post-treatment time (Fig. 4). A plausible explanation for these results may be the direct interaction between the oxon metabolites of chlorpyrifos (chlorpyrifosoxon) and $\mathrm{CbE}$ activity. It is generally accepted that impact of pesticides on soil enzymes is difficult to predict because of multiple direct and indirect effects jointly affecting the enzyme activity, which results in an increase, decrease or no change of its catalytic activity (Gianfreda and Rao, 2008; Floch et al., 2011; Riah et al., 2014). However, past studies (Cacco and Maggioni, 1976; Satyanarayana and Getzin, 1973), and a recent work by Sanchez-Hernandez et al. (2017), have showed that the response of soil $\mathrm{CbE}$ activity to organophosphorus pesticides is the result of a direct interaction of the oxon metabolite of the organophosphate with the enzyme probably via a comparable mechanism like that occurring in organisms, i.e., phosphorylation of the active site of the enzyme (Chambers et al., 2010). As a matter of fact, this direct chemical interaction would reduce the organophosphorus bioavailability and toxicity. Therefore, the high inhibition degree of soil CbE activity observed in the first weeks following chlorpyrifos treatment might be assumed as a 'buffer effect' by which the generation of the toxic chlorpyrifos-oxon is inactivated by CbEs. This chemical interaction, in turn, would alleviate toxic effect of chlorpyrifos-oxon on the other soil enzymes (Fig. 4).

Our results also demonstrated that the addition of earthworms or litter to soils reduced the negative impact of chlorpyrifos on soil microbial activity, as assessed by the dehydrogenase activity (Fig. 4). This enzyme activity remained significantly inhibited in the chlorpyrifos-spiked soils free of both earthworms and litter for the entire incubation period (26.2-39.0\% inhibition compared with chlorpyrifos-free soils). This result confirms previous studies that demonstrated chlorpyrifos, or chlorpyrifos-oxon, inhibits soil microbial proliferation (Singh and Walker, 2006; John and Shaike, 2015). However, correlation analysis of our data evidenced significant relationships $(r>0.68, P<0.05)$ between dehydrogenase activity and the rest of enzyme activities in the soil from the high-density treatment compared with soil from the control treatment (Supplementary Fig. S1). These data suggested the presence of $L$. terrestris in chlorpyrifos-contaminated soils had an indirect effect on restoration of soil enzyme activities through microbial stimulation and propagation in the bulk soil.

\subsection{Effect of earthworm feeding on soil enzyme activities}

In line with our third aim, we determined whether the gastrointestinal transit of soil contributed to decrease soil enzyme activities. During the digestion, hydrolytic enzymes (e.g., chitinases, cellulases, xylanases, amilases, lipases, esterases and proteases) increase their activity in the first intestinal segment (foregut) of earthworms, to decrease drastically and progressively as the luminal content progresses until its final excretion in the form of casts (Lattaud et al., 1998; Zhang et al., 1993; Sanchez-Hernandez et al., 2009). The occurrence of proteases seems to be the most plausible reason for this decrease of luminal enzymes in the earthworm gastrointestinal tract (Tillinghast et al., 2001).

We measured some enzyme activities in cast freshly $(<24 \mathrm{~h})$ deployed by earthworms and, contrary to our initial expectations, the dynamics of enzyme activities in this material matched that in the bulk soil. A significant decrease of the enzyme activities was found in the 2nd week of chlorpyrifos exposure, followed by a progressive recovery, which depended on the enzyme type (Fig. 5). Adsorption of extracellular enzymes, whose microbial production was indirectly stimulated by earthworms (Supplementary Fig. S1A), to soil organo-mineral complexes probably provided protection from proteolysis and microbial degradation in the gut microenvironment. However, what is surprising was that levels of CbE activity in cast did not differ between low- and high-density treatments (Fig. 5A). This observation might be explained by the fact that the gastrointestinal epithelium of $L$. terrestris is a significant source of luminal $\mathrm{CbE}$ activity (Sanchez-Hernandez et al., 2009), so the high intestinal production of this esterase could mask any difference of enzyme activity between both experimental groups. In fact, whereas the mean $( \pm \mathrm{SD})$ CbE activity in the bulk soil was $1.58 \pm 0.30 \mu \mathrm{mol} \mathrm{h}^{-1} \mathrm{~g}^{-1}$ dry mass (low-density treatment) and $3.00 \pm 0.68$ (high-density treatment) after $18 \mathrm{wk}$. of incubation, the mean enzyme activity measured in the casts was $5.48 \pm 2.02$ (low-density treatment) and $5.07 \pm 0.92 \mu \mathrm{mol} \mathrm{h}{ }^{-1} \mathrm{~g}^{-1}$ dry mass (high-density treatment). In view of this, we could infer that $L$. terrestris plays an important role in pesticide-contaminated soils as biological vectors of soil $\mathrm{CbE}$ production and dispersion; a key enzyme in the inactivation of toxic oxon metabolites from organophosphorus pesticides.

\section{Conclusions}

Treatment of chlorpyrifos-contaminated soils with L. terrestris did not accelerate degradation of the pesticide, however, earthworms had a beneficial impact on soil quality. Soil enzyme activities increased progressively as chlorpyrifos concentration decreased, reaching values even higher than those recorded before the pesticide application. This stimulatory impact of earthworms took place despite organisms showed signs of severe intoxication (90\% inhibition of muscle AChE and $\mathrm{CbE}$ activities) and oxidative stress. Our findings suggest, therefore, that $L$. terrestris is a suitable candidate to retain, or even improve, the biochemical performance of organophosphorus-contaminated soils at long-term scale, and simultaneously, to serve as a sentinel for assessing soil toxicity during bioremediation.

\section{Acknowledgement}

This work has been supported by the Spanish Ministerio de Economía y Competitividad (grants no. CTM2011-25788 and CTM2014-53915-R) and the regional government Junta de Comunidades de Castilla-La Mancha (grant no. PEII-2014-001-P). We greatly appreciate the suggestions and constructive comments from three anonymous reviewers, which have contributed to improve the manuscript.

\section{Appendix A. Supplementary data}

Supplementary data to this article can be found online

\section{References}

Agarwal, R., Chase, S.D., 2002. Rapid, fluorimetric-liquid chromatographic determination of malondialdehyde in biological samples. J. Chromatogr. B 775, 121-126.

Arias-Estévez, M., López-Periago, E., Martínez-Carballo, E., Simal-Gándara, J., Mejuto, J.-C., García-Río, L., 2008. The mobility and degradation of pesticides in soils and the pollution of groundwater resources. Agric. Ecosyst. Environ. 123, 247-260.

Bolan, N.S., Baskaran, S., 1996. Characteristics of earthworm casts affecting herbicide sorption and movement. Biol. Fertil. Soils 22, 367-372.

Bonnail, E., Buruaem, L.M., Araujo, G.S., Abessa, D.M.S., DelValls, T.Á., 2016. Multiple biomarker responses in Corbicula fluminea exposed to copper in laboratory toxicity tests. Arch. Environ. Contam. Toxicol. 71, 278-285.

Burns, R.G., DeForest, J.L., Marxsen, J., Sinsabaugh, R.L., Stromberger, M.E., Wallenstein, M.D., Weintraub, M.N., Zoppini, A., 2013. Soil enzymes in a changing environment: current knowledge and future directions. Soil Biol. Biochem. 58, 216-234.

Butt, K.R., 2008. Earthworms in soil restoration: lessons learned from United Kingdom case studies of land reclamation. Restor. Ecol. 16, 637-641.

Cacco, G., Maggioni, A., 1976. Multiple forms of acetyl-naphthyl-esterase activity in soil organic matter. Soil Biol. Biochem. 8, 321-325.

Chambers, J., Meek, E., Chambers, H., 2010. The metabolism of organophosphorus insecticides. In: Krieger, R. (Ed.), Hayes' Handbook of Pesticide Toxicology. Elsevier, New York (USA), pp. 1399-1407.

Collange, B., Wheelock, C.E., Rault, M., Mazzia, C., Capowiez, Y., Sanchez-Hernandez, J.C., 2010. Inhibition, recovery and oxime-induced reactivation of muscle esterases following chlorpyrifos exposure in the earthworm Lumbricus terrestris. Environ. Pollut. 158, 2266-2272.

Dempsey, M.A., Fisk, M.C., Yavitt, J.B., Fahey, T.J., Balser, T.C., 2013. Exotic earthworms alter soil microbial community composition and function. Soil Biol. Biochem. 67, 263-270. 
Devine, G.J., Furlong, M.J., 2007. Insecticide use: contexts and ecological consequences. Agric. Hum. Values 24, 281-306.

Dick, R.P., Pankhurst, C., Doube, B.M., Gupta, V., 1997. Soil enzyme activities as integrative indicators of soil health. In: Pankhurst, C.E., Doube, B.M., Gupta, V.V.S.R. (Eds.), Biological Indicators of Soil Health. CAB International, pp. 121-156.

Edwards, C.A., 2004. Earthworm Ecology. 2nd ed. CRC Press, Boca Raton, Florida (USA).

Erel, O., 2004. A novel automated direct measurement method for total antioxidant capacity using a new generation, more stable ABTS radical cation. Clin. Biochem. 37, 277-285.

Fenoll, J., Vela, N., Navarro, G., Pérez-Lucas, G., Navarro, S., 2014. Assessment of agro-industrial and composted organic wastes for reducing the potential leaching of triazine herbicide residues through the soil. Sci. Total Environ. 493, 124-132.

Floch, C., Chevremont, A.-C., Joanico, K., Capowiez, Y., Criquet, S., 2011. Indicators of pesticide contamination: soil enzyme compared to functional diversity of bacterial communities via Biolog® Ecoplates. Eur. J. Soil Biol. 47, 256-263.

Fründ, H.-C., Butt, K., Capowiez, Y., Eisenhauer, N., Emmerling, C., Ernst, G., Potthoff, M., Schädler, M., Schrader, S., 2010. Using earthworms as model organisms in the laboratory: recommendations for experimental implementations. Pedobiologia 53, 119-125.

Fukuto, T.R., 1990. Mechanism of action of organophosphorus and carbamate insecticides. Environ. Health Perspect. 87, 245-254.

Gao, Y.-C., Wang, J.-N., Xu, J.-B., Kong, X., Zhao, L., Zeng, D.-H., 2013. Assessing the quality of oil-contaminated saline soil using two composite indices. Ecol. Indic. 24, 105-112.

Gianfreda, L., Rao, M.A., 2008. Interactions between xenobiotics and microbial and enzymatic soil activity. Crit. Rev. Environ. Sci. Technol. 38, 269-310.

Hernández-Soriano, M.C., Mingorance, M.D., Peña, A., 2009. Dissipation of insecticides in a Mediterranean soil in the presence of wastewater and surfactant solutions. A kinetic model approach. Water Res. 43, 2481-2492.

Hickman, Z.A., Reid, B.J., 2008. Earthworm assisted bioremediation of organic contaminants. Environ. Int. 34, 1072-1081.

Hinojosa, M.B., García-Ruíz, R., Viñegla, B., Carreira, J.A., 2004. Microbiological rates and enzyme activities as indicators of functionality in soils affected by the Aznalcóllar toxic spill. Soil Biol. Biochem. 36, 1637-1644.

Jager, T., Fleuren, R.H.L.J., Hogendoorn, E.A., de Korte, G., 2003. Elucidating the routes of exposure for organic chemicals in the earthworm, Eisenia andrei (Oligochaeta). Environ. Sci. Technol. 37, 3399-3404.

John, E.M., Shaike, J.M., 2015. Chlorpyrifos: pollution and remediation. Environ. Chem. Lett. 13, 269-291.

Kizilkaya, R., Karaca, A., Turgay, O.C., Cetin, S.C., 2010. Earthworm interactions with soil enzymes. In: Karaca, A. (Ed.), Biology of Earthworms. Springer, Berlin Heidelberg Berlin, Heidelberg, pp. 141-158.

Lattaud, C., Locati, S., Mora, P., Rouland, C., Lavelle, P., 1998. The diversity of digestive systems in tropical geophagous earthworms. Appl. Soil Ecol. 9, 189-195.

Lawrence, R.A., Burk, R.F., 1976. Glutathione peroxidase activity in selenium-deficient rat liver. Biochem. Biophys. Res. Commun. 71, 952-958.

Lessard, I., Sauvé, S., Deschênes, L., 2014. Toxicity response of a new enzyme-based functional diversity methodology for Zn-contaminated field-collected soils. Soil Biol. Biochem. 71, 87-94.

Li, K., Xing, B., Torello, W.A., 2005. Effect of organic fertilizers derived dissolved organic matter on pesticide sorption and leaching. Environ. Pollut. 134, 187-194.

Lowe, C.N., Butt, K.R., 2005. Culture techniques for soil dwelling earthworms: a review. Pedobiologia 49, 401-413.

Lu, H., Li, Z., Fu, S., Méndez, A., Gascó, G., Paz-Ferreiro, J., 2015. Combining phytoextraction and biochar addition improves soil biochemical properties in a soil contaminated with Cd. Chemosphere 119, 209-216.

Lukaszewicz-Hussain, A., 2010. Role of oxidative stress in organophosphate insecticide toxicity - short review. Pestic. Biochem. Physiol. 98, 145-150.

Ma, W.C., Bodt, J., 1993. Differences in toxicity of the insecticide chlorpyrifos to six species of earthworms (Oligochaeta, Lumbricidae) in standardized soil tests. Bull. Environ. Contam. Toxicol. 50, 864-870.

Mackay, D., Shiu, W.-Y., Ma, K.-C., Lee, S.C., 2006. Handbook of Physical-chemical Properties and Environmental Fate for Organic Chemicals. Vol. IV. CRC press.

Martinkosky, L., Barkley, J., Sabadell, G., Gough, H., Davidson, S., 2017. Earthworms (Eisenia fetida) demonstrate potential for use in soil bioremediation by increasing the degradation rates of heavy crude oil hydrocarbons. Sci. Total Environ. 580, 734-743.

Megharaj, M., Ramakrishnan, B., Venkateswarlu, K., Sethunathan, N., Naidu, R., 2011. Bioremediation approaches for organic pollutants: a critical perspective. Environ. Int. 37, 1362-1375.

von Mersi, W., Schinner, F., 1991. An improved and accurate method for determining the dehydrogenase activity of soils with iodonitrotetrazolium chloride. Biol. Fertil. Soils $11,216-220$.

Mijangos, I., Albizu, I., Epelde, L., Amezaga, I., Mendarte, S., Garbisu, C., 2010. Effects of liming on soil properties and plant performance of temperate mountainous grasslands. J. Environ. Manag. 91, 2066-2074.

Muangphra, P., Tharapoom, K., Euawong, N., Namchote, S., Gooneratne, R., 2015. Chronic toxicity of commercial chlorpyrifos to earthworm Pheretima peguana. Environ. Toxicol. 31, 1450-1459.

Muñoz-Leoz, B., Garbisu, C., Charcosset, J.-Y., Sánchez-Pérez, J.M., Antigüedad, I., RuizRomera, E., 2013. Non-target effects of three formulated pesticides on microbiallymediated processes in a clay-loam soil. Sci. Total Environ. 449, 345-354.

Nannipieri, P., 2006. Role of stabilised enzymes in microbial ecology and enzyme extraction from soil with potential applications in soil proteomics. In: Nannipieri, P., Smalla, K. (Eds.), Nucleic Acids and Proteins in Soil. Springer-Verlag, Berlin Heidelberg, pp. 75-94.
Paz-Ferreiro, J., Fu, S., 2013. Biological indices for soil quality evaluation: perspectives and limitations. Land Degrad. Dev. 27, 14-25.

Paz-Ferreiro, J., Fu, S., Méndez, A., Gascó, G., 2014. Interactive effects of biochar and the earthworm Pontoscolex corethrurus on plant productivity and soil enzyme activities. J. Soils Sediments 14, 483-494.

Puglisi, E., Del Re, A.A.M., Rao, M.A., Gianfreda, L., 2006. Development and validation of numerical indexes integrating enzyme activities of soils. Soil Biol. Biochem. 38 1673-1681.

Racke, K.D., 1993. Environmental fate of chlorpyrifos. Rev. Environ. Contam. Toxicol. 131 $1-150$.

Racke, K.D., Steele, K.P., Yoder, R.N., 1996. Factors affecting the hydrolytic degradation of chlorpyrifos in soil. J. Agric. Food Chem. 44, 1582-1592.

Ramos-Martinez, J.L., Rodriguez Bartolomé, T., Vazquez Pernas, R, 1983. Purification and properties of glutathione reductase from hepatopancreas of Mytilus edulis L. Comp. Biochem. Physiol. 75, 689-692.

Rault, M., Collange, B., Mazzia, C., Capowiez, Y., 2008. Dynamics of acetylcholinesterase activity recovery in two earthworm species following exposure to ethyl-parathion. Soil Biol. Biochem. 40, 3086-3091.

Riah, W., Laval, K., Laroche-Ajzenberg, E., Mougin, C., Latour, X., Trinsoutrot-Gattin, I., 2014. Effects of pesticides on soil enzymes: a review. Environ. Chem. Lett. 12 257-273.

Rodriguez-Campos, J., Dendooven, L., Alvarez-Bernal, D., Contreras-Ramos, S.M., 2014. Potential of earthworms to accelerate removal of organic contaminants from soil: a review. Appl. Soil Ecol. 79, 10-25.

Rodríguez-Liébana, J.A., Mingorance, M.D., Peña, A., 2014. Pesticide mobility and leachate toxicity in two abandoned mine soils. Effect of organic amendments. Sci. Total Environ. 497-498, 561-569.

Sanchez, W., Burgeot, T., Porcher, J.-M., 2013. A novel "integrated biomarker response" calculation based on reference deviation concept. Environ. Sci. Pollut. Res. 20, 2721-2725.

Sanchez-Hernandez, J.C., Mazzia, C., Capowiez, Y., Rault, M., 2009. Carboxylesterase activity in earthworm gut contents: potential (eco)toxicological implications. Comp. Biochem. Physiol. 150, 503-511.

Sanchez-Hernandez, J.C., Sandoval, M., Pierart, A., 2017. Short-term response of soil enzyme activities in a chlorpyrifos-treated mesocosm: use of enzyme-based indexes. Ecol. Indic. 73, 525-535.

Satyanarayana, T., Getzin, L.W., 1973. Properties of a stable cell-free esterase from soil Biochemist 12, 1566-1572.

Shan, J., Xu, J., Zhou, W., Ji, L., Cui, Y., Guo, H., Ji, R., 2011. Enhancement of chlorophenol sorption on soil by geophagous earthworms (Metaphire guillelmi). Chemosphere 82 $156-162$.

Shaw, L.J., Burns, R.G., 2006. Enzyme activity profiles and soil quality. In: Bloem, J., Hopkins, D.W., Benedetti, A. (Eds.), Microbiological Methods for Assessing Soil Quality. CAB International, Oxfordshire, UK, pp. 158-182.

Singh, B., Walker, A., 2006. Microbial degradation of organophosphorus compounds FEMS Microbiol. Rev. 30, 428-471.

Skjemstad, J., Baldock, J., 2008. Total and organic carbon. In: Carter, M.R., Gregorich, E.G. (Eds.), Soil Sampling and Methods of Analysis. CRC Press, Boca Raton, Florida (USA), pp. 225-237.

Sogorb, M.A., Vilanova, E., 2002. Enzymes involved in the detoxification of organophosphorus, carbamate and pyrethroid insecticides through hydrolysis. Toxicol. Lett. 128, 215-228.

Stavi, I., Bel, G., Zaady, E., 2016. Soil functions and ecosystem services in conventional conservation, and integrated agricultural systems. A review. Agron. Sustain. Dev. $36,1-13$.

Tao, J., Griffiths, B., Zhang, S., Chen, X., Liu, M., Hu, F., Li, H., 2009. Effects of earthworms on soil enzyme activity in an organic residue amended rice-wheat rotation agro-ecosystem. Appl. Soil Ecol. 42, 221-226.

Thompson, H.M., 1999. Esterases as markers of exposure to organophosphates and carbamates. Ecotoxicology 8, 369-384.

Tillinghast, E.K., O'Donnell, R., Eves, D., Calvert, E., Taylor, J., 2001. Water-soluble luminal contents of the gut of the earthworm Lumbricus terrestris L. and their physiological significance. Comp. Biochem. Physiol. 129, 345-353.

Tilman, D., Cassman, K.G., Matson, P.A., Naylor, R., Polasky, S., 2002. Agricultural sustainability and intensive production practices. Nature 418, 671-677.

Velki, M., Hackenberger, B.K., 2013. Inhibition and recovery of molecular biomarkers of earthworm Eisenia andrei after exposure to organophosphate dimethoate. Soil Biol. Biochem. 57, 100-108.

Vieira, C.E.D., Costa, P.G., Lunardelli, B., de Oliveira, L.F., da Costa Cabrera, L., Risso, W.E., Primel, E.G., Meletti, P.C., Fillmann, G., Martinez, Reis, Dos, C.B., 2016. Multiple biomarker responses in Prochilodus lineatus subjected to short-term in situ exposure to streams from agricultural areas in Southern Brazil. Sci. Total Environ. 542, 44-56.

Wheelock, C.E., Eder, K.J., Werner, I., Huang, H., Jones, P.D., Brammell, B.F., Elskus, A.A. Hammock, B.D., 2005. Individual variability in esterase activity and CYP1A levels in Chinook salmon (Oncorhynchus tshawytscha) exposed to esfenvalerate and chlorpyrifos. Aquat. Toxicol. 74, 172-192.

Wheelock, C.E., Phillips, B.M., Anderson, B.S., Miller, J.L., Miller, M.J., Hammock, B.D., 2008. Applications of carboxylesterase activity in environmental monitoring and toxicity identification evaluations (TIEs). Rev. Environ. Contam. Toxicol. 195, 117-178.

Yu, Y.L., Wu, X.M., Li, S.N., Fang, H., Zhan, H.Y., Yu, J.Q., 2006. An exploration of the relationship between adsorption and bioavailability of pesticides in soil to earthworm. Environ. Pollut. 141, 428-433.

Zhang, B.G., Rouland, C., Lattaud, C., Lavelle, P., 1993. Activity and origin of digestive enzymes in gut of the tropical earthworm Pontoscolex corethrurus. Eur. J. Soil Biol. 29 7-11. 